\title{
Plasmacytoid dendritic cells: neglected regulators of the immune response to Staphylococcus aureus
}

\author{
Isabelle Bekeredjian-Ding ${ }^{1}$, Johann Greil ${ }^{1,2}$, Sandra Ammann $^{3}$ and Marijo Parcina ${ }^{1}$ \\ 1 Institute for Microbiology, Immunology and Parasitology, University Hospital Bonn, Bonn, Germany \\ ${ }^{2}$ Department of Pediatrics, University Hospital Heidelberg, Heidelberg, Germany \\ ${ }^{3}$ Department of Infectious Diseases, Medical Microbiology and Hygiene, University Hospital Heidelberg, Heidelberg, Germany
}

Edited by:

Fabio Bagnoli, Novartis Vaccines, Italy

Reviewed by:

Eliana Marina Coccia, Istituto

Superiore di Sanità, Italy

Elisabetta Adelaide Pia Soldaini,

Novartis Vaccines, Italy

*Correspondence:

Isabelle Bekeredjian-Ding, Institute

for Microbiology, Immunology and

Parasitology, University Hospital

Bonn, Sigmund-Freud-Strasse 25,

D-53105 Bonn, Germany

e-mail: bekeredjian-ding@uni-bonn.de
Plasmacytoid dendritic cells (pDC) are a rare subset of leukocytes equipped with Fc $\gamma$ and Fce receptors, which exert contrary effects on sensing of microbial nucleic acids by endosomal Toll-like receptors. In this article, we explain how pDC contribute to the immune response to Staphylococcus aureus. Under normal circumstances the pDC participates in the memory response to the pathogen: $\mathrm{pDC}$ activation is initiated by uptake of staphylococcal immune complexes with IgG or IgE. However, protein A-expressing $S$. aureus strains additionally trigger pDC activation in the absence of immunoglobulin. In this context, staphylococci exploit the pDC to induce antigen-independent differentiation of IL-10 producing plasmablasts, an elegant means to propagate immune evasion. We further discuss the role of type I interferons in infection with $S$. aureus and the implications of these findings for the development of immune based therapies and vaccination.

Keywords: pDC, Staphylococcus aureus, type I interferons, immune complexes, bacteria, tolerance, autoimmunity, allergy

\section{INTRODUCTION}

Plasmacytoid dendritic cells (pDC) constitute a rare, but ubiquitously present leukocyte subset. They were originally described as professional interferon-producing cells (IPC) $(1,2)$, because of their capacity to secrete high concentrations of type I interferons (IFN-I) (mainly IFN- $\alpha$ ) that can reach systemic activity [reviewed in Ref. $(3,4)]$.

Numerous studies elucidate pDC function in different types of infection, autoimmune disease entities and in maintenance of tolerance [reviewed in Ref. (5)]. Most importantly, they have made us aware of the fact that there are pDC functions beyond IFN secretion. Despite their versatility only few studies described pDC activation and addressed its role in the host response to Staphylococcus aureus (6-12). Thus, their function in the daily combat with colonizing and infecting $S$. aureus strains remains to be investigated. In this article, we summarize the available findings and discuss the potential implications for immune based therapies and vaccine design.

\section{WELL-EQUIPPED VIRAL SENSORS}

Type I interferons are essential for antiviral immune defense. Early studies postulated that pDC represent specialized viral sensors in first line innate immune defense against viruses [reviewed in Ref. (13)]. Identification of Toll-like receptors (TLR)- 7 and -9 as the major triggers for $\mathrm{pDC}$ activation fostered this concept because RNA viruses such as influenza, RSV, VSV and HIV engage TLR7, and DNA viruses, i.e., HSV and EBV, activate pDC in a TLR9dependent manner. Nevertheless, under defined circumstances cytosolic, RIG-I like-receptor-dependent recognition also occurs $(8,14-16)$.

Subsequent studies elucidated pDC-mediated effects on the adaptive immune response. The major findings implied that pDC-derived IFN- $\alpha$ supports Th1 responses [reviewed in Ref. (17)] and enhances the formation of antibody secreting cells in response to virus (18).

The relevance of $\mathrm{pDC}$ and IFN-I in antiviral immune defense is strongly supported by the multitude of viral immune escape mechanisms interfering with the induction of IFN-I or its direct effect on intracellular viral replication. Depletion of pDC in in vivo infection models revealed that $\mathrm{pDC}$ contribute to virus clearance and constrain inflammation during infection (19-21). Concomitant expression of HIV permissive receptors, i.e., CD4, CXCR4, CCR5 [reviewed in Ref. $(22,23)]$, and viral restriction factors (Figure 1A, left panel), i.e., APOBEG3G (24), CD317/tetherin/BST2 (25), ILT7 (26), and SamHD1 turns pDC into "viral traps," e.g., important target cells for viral infection albeit well-equipped and highly specialized on intracellular antiviral defense (Figure 1A, left panel).

\section{PERPETUATORS OF AUTOIMMUNE DISEASE AND ALLERGY}

Due to their highly efficient IFN- $\alpha$ producing capacity it was obvious that $\mathrm{pDC}$ might be involved in autoimmune disease. In this disease context, $\mathrm{pDC}$ were shown to be activated by immune complexes (IC) consisting of autoantibodies binding endogenous chromatin or RNA and activating TLR9 or TLR7, respectively [reviewed in Ref. (27-30)]. Uptake of IC was mediated via Fc $\gamma$ RIIA $(\mathrm{CD} 32 \mathrm{~A})$, a positive regulatory receptor for IgG (Figure 1A, middle panel). IC-induced pDC-derived IFN- $\alpha$ is thought to account for elevated IFN-I levels in patients with systemic lupus erythematosus, Behcet's disease, and Sjögren's syndrome (31-33). The ubiquitous presence of pDC facilitates systemic effects of IFN$\alpha$. This cytokine contributes to the development and severity of disease by enhancing autoantibody production and driving inflammation [reviewed in Ref. (34)]. 


\section{A pDC effector function}

\author{
I. Sensors for intracellular \\ pathogens
}

\section{Immune complex-mediated activation}

\section{Tolerance induction}

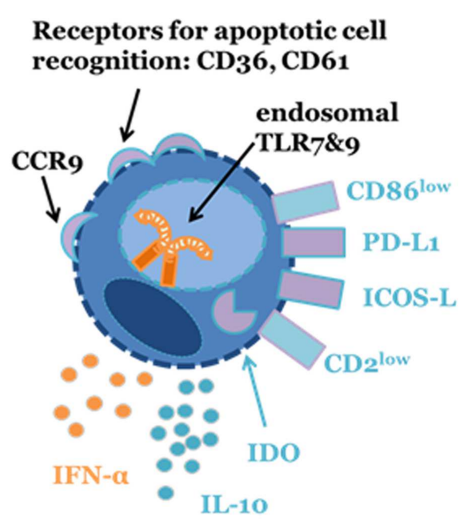

\section{B Recognition of $S$. aureus}

I. Bacterial immune complex

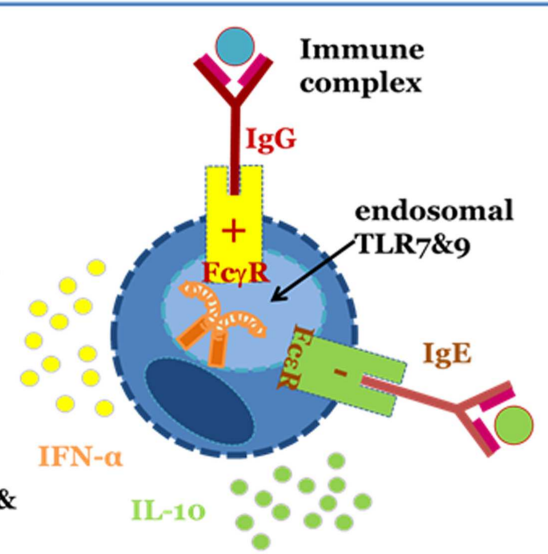

Immune

CD4, CXCR4 \& CCR5

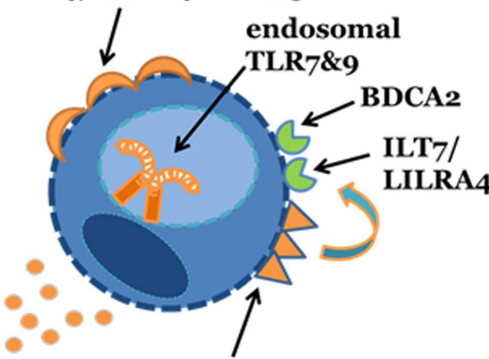

IFN- $\alpha$ Viral restriction factors $\mathrm{APOBEC}_{3} \mathrm{G}, \mathrm{CD}_{317} /$ tetherin \& SamHD1

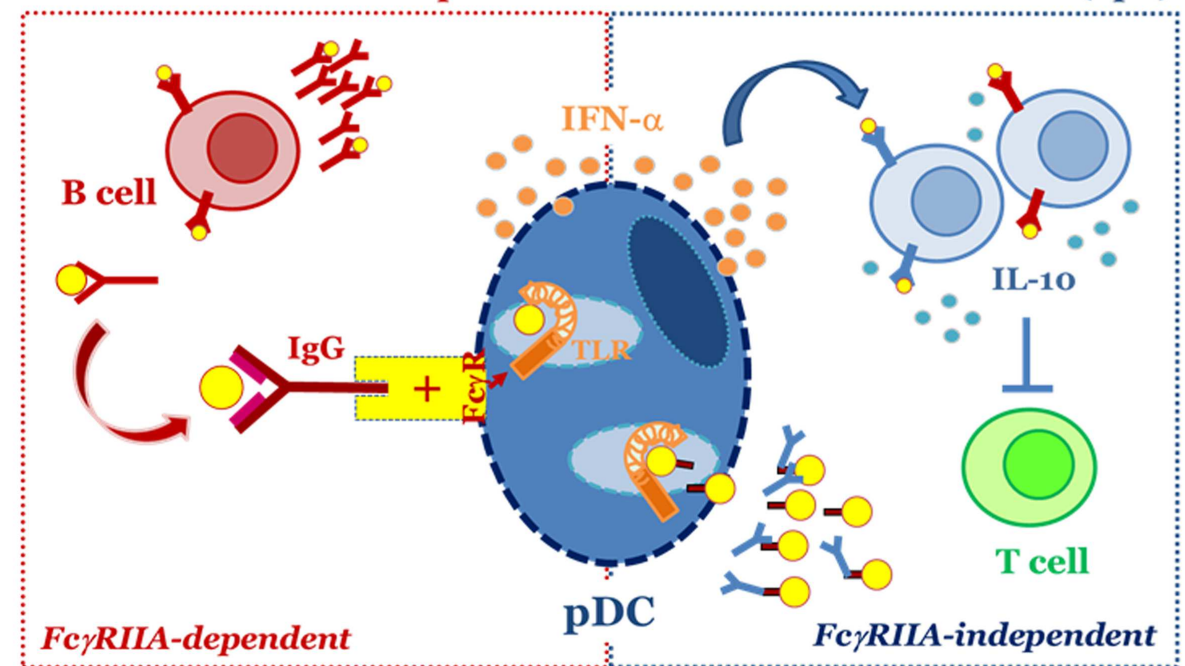

$\bigcirc-\begin{aligned} & \text { S. aureus : IgG } \\ & \text { immune complex }\end{aligned} \quad-\operatorname{SpA}^{\text {hi }}$ S. aureus

FIGURE 1 | Plasmacytoid dendritic cells function in different immune contexts. (A) pDC fulfill different effector functions. I. Sensors for intracellular pathogens. $\mathrm{pDC}$ are target cells for viral infection because they express cell surface receptors utilized for virus entry, i.e., HIV permissive receptors CD4, CXCR4, and CCR5. Endosomal TLR7 and TLR9 mediate recognition of RNA and DNA viruses, respectively. IFN-I synthesis and viral restriction factors counteract viral infection and intracellular replication. Surface receptors such as ILT7 and BDCA2 regulate $\mathrm{pDC}$ function. II. Immune complex-mediated activation. pDC express Fc $\gamma$ RIIA and FceRI. These receptors are engaged by immune complexes consisting of IgG and bacteria, viruses or endogenous nucleic acids or lgE-bound allergens. Binding of FcyRIIIA promotes access of IgG-complexed nucleic acids to endosomal TLR and enables $\mathrm{pDC}$-derived IFN- $\alpha$ release. FceRI ligation inhibits TLR9-induced IFN- $\alpha$ secretion and induces IL-10 production and Th2 polarization. III. Tolerance induction. pDC promote tolerance via induction of Treg. Tolerogenic function has been associated with high PDL-1 and low
CD86 expression, release of IL-10, expression of CCR9, IDO, ICOS-L, and low CD2. Expression of CD36 and CD61 among other surface receptors enables apoptotic cell recognition. (B) $S$. aureus-induced pDC activation occurs in an FcyRIIA-dependent (I) and -independent (II) fashion. I (left): pDC are activated by bacterial immune complexes (IC) with anti-staphylococcal $\lg$. This activation requires prior generation of $\lg G$ and therefore forms part of a secondary immune response. IC-mediated engagement of the Fc $\gamma$ RIIA promotes access of staphylococcal nucleic acids to endosomal TLR7/9, which induces secretion of IFN- $\alpha$. II (right): $S$. aureus strains expressing high levels of protein $A(S p A)$ stimulate $p D C$ in the absence of $\lg G$ and IC formation. This virulence factor-dependent mechanism for $\mathrm{pDC}$ activation triggers release of IFN- $\alpha$ via activation of endosomal TLR7/9. Activated pDC support SpA-dependent B cell expansion and differentiation into IL-10 secreting plasmablasts. B cell-derived IL-10 production, a hallmark of regulatory $\mathrm{B}$ cell function, prevents $\mathrm{T}$ cell responses by inhibiting antigen presentation by dendritic cells and macrophages. 
Similarly to autoantigens allergens complexed with IgE can activate $\mathrm{pDC}$. However, ligation of the FceRI expressed on $\mathrm{pDC}$ has quite distinct effects from those induced via Fc $\gamma$ RIIA activation: FceRI aggregation has negative regulatory impact on influenza virus and TLR9-mediated release of IFN-I from pDC (35-37). On the contrary, aggregation of the FceRI promotes IL-10 secretion and shifts the $\mathrm{T}$ cell response toward an allergy related-Th2 response (35), an effect supported by the absence of IFN-I. A correlation of serum $\mathrm{IgE}$ with an increased $\mathrm{pDC} / \mathrm{mDC}$ ratio and a Th2 response underlines the clinical relevance of these findings $(35,36,38)$.

Taken together, these examples demonstrate that pDC function varies depending on the disease entity. They highlight the dominant role of $\mathrm{IC}$ recognition in $\mathrm{pDC}$ activation and the opposite effects of differentially composed IC on pDC function.

\section{MEDIATORS OF TOLERANCE}

More recently, several groups have drawn our attention to the tolerogenic properties of pDC [reviewed in Ref. $(5,39)]$. This includes immune regulatory function in graft-versus-host disease (40-42), cancer $(26,43)$, infection (44-46), autoimmune disease (47-49), and tolerance to oral antigens (50). Furthermore, pDC recognize membrane microparticles released from apoptotic cells $(16,51)$ and play a crucial role in the promotion of tolerance upon apoptotic cell recognition (52).

To date the tolerogenic function has been attributed to the induction of $\mathrm{T}$ regulatory cells $(44,53-59)$. Release of pDCderived IL-10 and expression of IDO, PD-L1, and ICOS-L represent the mainstay for Treg induction (51, 54, 55, 57, 60-67) (Figure 1A, right panel). Furthermore, pDC effector function is subject to strong regulation by the cellular environment $(43,44$, 60, 68-70): while TGF $\beta$ exposure promotes pDC-derived secretion of high levels of IL- 6 and development of Th17 cells (71), soluble factors released from macrophages exposed to apoptotic cells prime pDC for Treg induction (52). Furthermore, TNF, ROS, IL-10, $\mathrm{PGE}_{2}$, and TGF $\beta$ in Peyer's patches, tumor cells, or adjacent monocytes modulate cytokine secretion patterns and decrease IFN- $\alpha$ secretion levels in pDC $(68,72-75)$, concomitantly reducing their Th1 induction potential [reviewed in Ref. (76)].

In this context, it is further important to note that IFN-I do not exclusively act as amplifiers of inflammatory processes but also participate in Treg induction and suppression of T cells, B cells, and innate immune cells $(17,77-89)$. Depending on the cellular context pDC-derived IFN-I may, thus, play a role in terminating or perpetuating the adaptive immune response.

\section{RECOGNITION OF STAPHYLOCOCCUS AUREUS SENSING OF STAPHYLOCOCCUS AUREUS}

For a long time, $\mathrm{pDC}$ were considered specialized mediators of antiviral defense and only few reports addressed their ability to respond to fungi and bacteria [reviewed in Ref. (90)]. These studies focused on intracellular bacteria (91-96). Induction of IFN-I by extracellular bacteria, was only observed with Escherichia coli and, most importantly, S. aureus (9-11, 97, 98). The cellular source and the molecular mechanism triggering IFN-I release remained ill-defined.
This prompted us to investigate how $S$. aureus induces IFNI secretion. Our data identified $\mathrm{pDC}$ as the major source for $S$. aureus-induced release of IFN- $\alpha$ from human peripheral blood leukocytes $(7,8)$. This finding confirmed earlier reports on IFN- $\alpha$ secretion in response to stimulation with $S$. aureus in a murine DC cell line (9) and initial descriptions of $S$. aureus-responsive IPCs $(10,11)$. Michea et al. further demonstrated uptake of $S$. aureus into pDC and secretion of IFN- $\alpha$, TNF, and IL-6 (6). We further detected pDC-derived IL- $1 \beta$ secretion and low levels of IL-10 in response to $S$. aureus (7).

As with viruses any inhibition of endosomal maturation and of TLR7 and TLR9 activation interfered with S. aureus-mediated IFN- $\alpha$ secretion $(7,8)$ and staphylococcal DNA and RNA induced pDC-derived IFN- $\alpha$ production (8). Furthermore, stimulation with viable staphylococci was superior to that induced by nonreplicating (heat- or UV-killed) cells, a finding attributed to a higher content in microbial nucleic acids and the presence of vitaPAMPs (99). Thus, pDC-derived IFN- $\alpha$ secretion triggered by $S$. aureus is driven by intracellular nucleic acid recognition.

Moreover, soluble factors released from tonsillar epithelial cells exposed to S. aureus inhibit pDC-derived cytokine production (6) and release of IFN- $\alpha$ in response to $S$. aureus was reduced in $\mathrm{pDC}$ isolated from patients suffering of hepatitis B virus infection (100). Taken together, these data highlight the importance of the cellular environment in the regulation of $\mathrm{pDC}$ function in $S$. aureus infection.

\section{PDC ACTIVATION FORMS PART OF THE MEMORY RESPONSE TO S. AUREUS}

Interestingly, the available reports indicated that only $S$. aureus triggers IFN- $\alpha$, while other extracellular bacteria including coagulase negative staphylococci or Streptococcus pyogenes lack the ability to activate pDC $(8,90,101)$. Figure 2 A elucidates a key finding: rapid uptake of $S$. aureus into $\mathrm{pDC}$ is mediated by human serum containing IgG, but is absent if pDC are stimulated in serum lacking Ig with binding affinity to human Fc $\gamma$ Rs (chicken serum). Furthermore, neutralization of the Fc $\gamma$ RIIA on pDC or absence of serum IgG blocks bacterial endocytosis and, thus, prevents access of bacterial nucleic acid to endosomal TLRs and subsequent IFN- $\alpha$ induction (8).

Altogether, it became clear that $S$. aureus-induced release of pDC-derived IFN- $\alpha$ depends on the formation of bacterial IC as propagated in autoimmune disease (8) (Figure 1B, left panel). These complexes contain anti-bacterial IgG that engages the Fc $\gamma$ RIIA and promotes uptake of bacteria. Consequently, pDC activation occurs in an antigen-specific manner, e.g., S. aureusspecific IgG was required for the induction of IFN- $\alpha$ release. This was demonstrated by the absence of IFN- $\alpha$ induction when IC formation was prevented by use of a $S$. aureus strain deficient in the antigen targeted by the antibody (8).

The existence of strain- or species-specific serum IgG antibody is, thus, a key determinant in IC-induced pDC activation (8). Due to continuous exposure of humans (and animals) to S. aureus sera normally contain IgG specific for $S$. aureus, which explains their predisposition to respond to $S$. aureus with IFN- $\alpha$ production. This observation further explains why other extracellular bacteria lack IFN induction potential: they are less likely to mount an IgG 

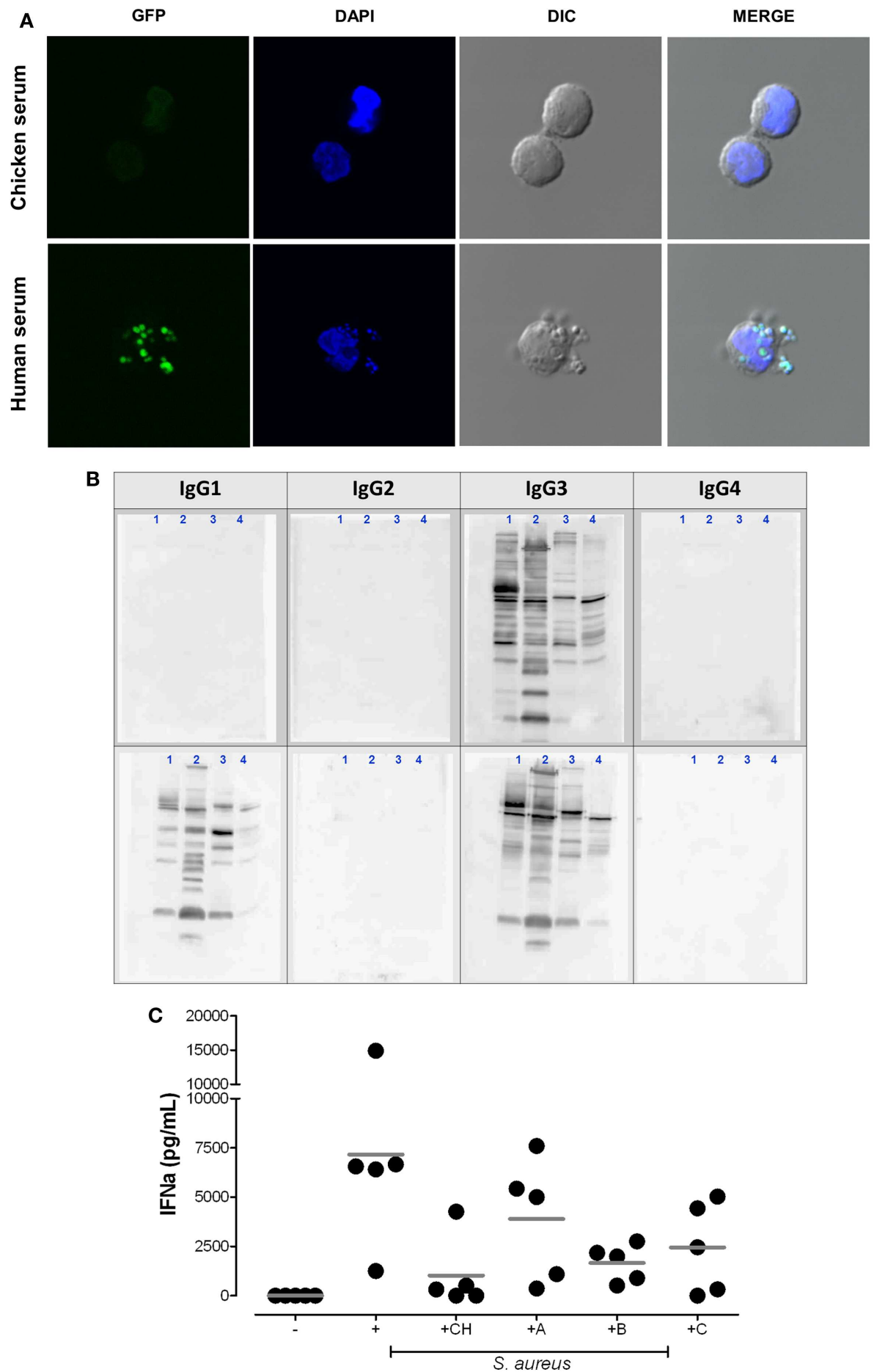

FIGURE 2 | Plasmacytoid dendritic cell activation by $\boldsymbol{S}$. aureus requires the uptake of bacterial immune complexes. (A) Cellular uptake of $S$. aureus depends on the presence of mammalian IgG. pDC were purified with anti-BDCA-4 microbeads and stimulated for $2 \mathrm{~h}$ at $37^{\circ} \mathrm{C}$ with heat-inactivated $\left(1 \mathrm{~h} 65^{\circ} \mathrm{C}\right.$ ) GFP-expressing $S$. aureus strain SA 113 WT (green) in medium supplemented with $5 \%$ chicken serum (upper panel) or $5 \%$ human serum (lower panel) at $37^{\circ} \mathrm{C}$. DAPI (blue) was used as nuclear counterstain. Cells were visualized by confocal microscopy. $(\mathbf{B}, \mathbf{C}) \lg G$ subclass requirements for bacterial immune complex formation. (B) Western blot analysis of IgG subclass distribution in two patients with selective lgG deficiency. Bacterial protein lysates from USA300 (1), Newman (2), Wood46 (3), and SA113 $\Delta$ spa (4) were loaded on SDS-PAGE. Western blot analysis visualizes the lgG subclasses present in serum from patient 1 ( $\left(\mathrm{gG}_{3}\right.$ only) and patient 2 ( $\operatorname{lgG}_{1}$ and $\operatorname{lgG}_{3}$ only, selective $\operatorname{lgG}_{2 / 4}$-deficiency). Membranes were incubated with serum followed by biotinylated anti-human IgG subclass antibodies and streptavidin-HRP as described in Ref. (7). (C) pDC medium was supplemented with $5 \%$ chicken serum $(\mathrm{CH})$, autologous serum [healthy adult donor $(\mathbf{A})$ ], or serum from patient 1 (B) or patient 2 (C). IFN- $\alpha$ release from $\mathrm{pDC}$ was quantified in the supernatants after $24 \mathrm{~h}$ stimulation. The graph summarizes the results obtained in five experiments with independent pDC donors. 
memory response because humans are either rarely exposed to the bacterial species (for example $S$. carnosus found in meat) or they do not trespass the skin and/or mucosal barriers and, thus, remain secluded from the blood and lymphoid compartments and the necessity to mount an IgG response (for example S. epidermidis, resident of the skin). As a consequence, only individual donors display a pDC response to coagulase negative staphylococci while donor pDC normally respond to $S$. aureus.

To further elucidate the IC composition we retrieved to sera from children with selective IgG deficiencies. The data obtained showed that the presence of anti-S. aureus $\operatorname{IgG}_{1}$ and/or $\operatorname{IgG}_{3}$ (Figure 2B) is sufficient for the induction of pDC-derived IFN$\alpha$ (Figure 2C). Thus, the presence of $\mathrm{IgG}_{2}$ and $\mathrm{IgG}_{4}$ does not represent a prerequisite for $\mathrm{pDC}$ activation.

Taken together, the available findings imply that prior generation of $S$. aureus-specific $\operatorname{IgG}_{1 / 3}$ is a mainstay for pDC activation. We, therefore, previously proposed that $\mathrm{pDC}$ activation is part of the secondary immune response to the microbe (Figure 1B, left panel). Notably, Fc $\gamma$ RII-dependent induction of IFN-I or activation of $\mathrm{pDC}$ was also reported for viruses that do not actively infect pDC (102-107). We, therefore, concluded that IC-mediated $\mathrm{pDC}$ activation represents the physiological immune response to infection.

\section{EXPLOITING pDC FOR IMMUNE EVASION}

It is well acknowledged that $S$. aureus induces $T$ cell-independent polyclonal $\mathrm{B}$ cell activation by targeting of $\mathrm{V}_{\mathrm{H}} 3+\mathrm{B}$ cell receptors with the immunoglobulin-binding protein "protein A" (108). Similarly to B cells, staphylococcal protein A also induces pDC-derived IFN- $\alpha$, thus circumventing the requirement for $S$. aureus-specific IgG and IC formation (7). These findings incremented earlier reports that proposed a role for protein A in IPC activation (10, 12). This alternative, albeit weaker, mechanism for pDC activation is, again, mediated by bacterial nucleic acid recognition because interference with endosomal TLR signaling abrogated pDC-derived IFN- $\alpha$ secretion (7). However, the exact cellular mechanisms mediating protein A-dependent uptake of nucleic acids into $\mathrm{pDC}$ remain to be clarified. Based on the results shown in Figure 2A, it can be speculated that IC/Fc $\gamma$ RIIA-mediated pDC activation promotes rapid uptake of whole bacteria while protein A-induced activation could be slower, less efficient, and might be mediated by protein A-bearing peptidoglycan particles complexed with nucleic acids.

Nevertheless, this form of $\mathrm{pDC}$ activation is noteworthy, because it depends on a bacterial virulence factor. It, therefore, resembles viral $\mathrm{pDC}$ infection and might contribute to disease pathology rather than immune defense (Figure 1B, right panel).

Interestingly, protein A-dependent cytokine induction mainly affected pDC-derived IFN- $\alpha$ and, additionally, monocyte-derived IL-10 (7). Well in line with a report on the immune recognition of S. aureus in monocytes (109) we did not detect IFN- $\alpha$ secretion in monocytes. IL-1 $\beta$ levels in monocytes were lower than those in pDC and did not correlate with protein A expression levels (7), a finding well compatible with its induction by a completely distinct set of bacterial and host factors, i.e., hemolysins, peptidoglycan degradation, ATP, ASC, cryopyrin, and Nlrp3 inflammasome activation (110-114).
What is more, activation of B cells was not only paralleled by $S$. aureus-induced activation of $\mathrm{pDC}$ but presence of $\mathrm{pDC}$ was a requirement for $\mathrm{B}$ cell proliferation and differentiation in response to stimulation with $S$. aureus (7). Although, synergy of $\mathrm{B}$ cells and $\mathrm{pDC}$ has been described in other contexts (115-119), it is often viewed as an effect of IFN-I on B cells. However, IFN- $\alpha$ inhibited $S$. aureus-induced B cell proliferation as in Ref. (120-122) and pDC function cannot be substituted by IFN- $\alpha$ or pDC supernatants indicating that cell-to-cell contact is required $(7,119)$.

Altogether, this study highlighted the fundamental role of $\mathrm{pDC}$ in promoting polyclonal B cell expansion and mediating B cellderived IL-10 production in an IFN-I independent manner (7). Based on these results, we propose that $S$. aureus exploits pDC to trigger polyclonal expansion of "regulatory B cells" and suppression of anti-bacterial T cell responses by B cell-derived IL-10 (123) (Figure 1B, right panel).

\section{ROLE OF TYPE I INTERFERON IN S. AUREUS INFECTION}

In contrast to virus infection, the role of IFN- $\alpha / \beta$ production in innate defense against bacterial pathogens is less clear and often paradox. While IFN $\alpha$ R signaling in some cases is required for bacterial clearance $(124,125)$, it supports hyperinflammation and increases disease severity in others (126). Albeit earlier studies reported release of IFN- $\alpha$ from human PBL in response to $S$. aureus $(9-12,127)$ a more recent study demonstrated that lysozyme resistance of $S$. aureus prevents IFN- $\beta$ induction (109). Degradationsensitive mutants induced higher levels of IFN- $\beta$, which mediated bacterial clearance in vitro and in vivo at the cost of increased inflammation and necrosis in vivo. IFN- $\beta$ induction in monocytes was MyD88-dependent but independent of TLR, thus, arguing for a role of IL-1 $\beta$ or IL-18 and the inflammasome in this process. Alternatively, in the murine model TLR13-mediated sensing of staphylococcal RNA might play a contributory role in $S$. aureus recognition (128).

In other $S$. aureus infection models lack of IFN $\alpha$ R or TLR9 protects mice against $S$. aureus pneumonia $(129,130)$, an observation attributed to reduced inflammation. On the contrary, IFN-I release in LCMV infection decreases IL-12 and IFN $\gamma$ production in response to $S$. aureus and predisposes mice for superinfection with $S$. aureus by inducing neutropenia $(131,132)$. Nevertheless, CpG ODN-mediated induction of IFN- $\alpha$ in pDC was protective against $S$. aureus pneumonia in a hemorrhagic shock model (133) and IFN $\alpha$ mediated resistance of host cells against $S$. aureus alpha toxin (134). In views of these conflicting results, we conclude that the role of type I interferon in the immune response to $S$. aureus is still ill-defined.

\section{IMPLICATIONS AND OUTLOOK}

Our summary of pDC function in the immune response illustrated that $\mathrm{pDC}$ function depends on the cellular environment and the disease entity (Figure 1A). pDC and IFN-I have partially overlapping functions and exert numerous, partially antagonistic regulatory functions within the immune response. The complexity of this cooperation is hard to tackle.

In the context of $S$. aureus infection, we have proposed that $\mathrm{pDC}$ serve two purposes (Figure 1B): firstly (Figure 1B, left panel), pDC 
respond to uptake of IgG-containing bacterial IC with production of IFN- $\alpha$. Thus, $\mathrm{pDC}$ activation forms part of the secondary immune response to the pathogen. Here, $\mathrm{pDC}$ might enhance the efficacy of memory $\mathrm{T}$ and $\mathrm{B}$ cell responses and possibly limit the priming of naïve lymphocytes. Furthermore, preferential formation of anti-staphylococcal $\operatorname{IgG}_{4}$, an IgG subclass with low affinity to the human Fc $\gamma$ RIIA $(7,135-137)$, could contribute to avoidance of pDC activation by $\operatorname{IgG}_{1}$ and $\mathrm{IgG}_{3}$-bearing IC (Figures 2B,C), thereby weakening the memory response.

Notably, to date no study has addressed the role of IC consisting of bacteria and IgE in pDC activation. Since it is well-known that there is significant production of IgE against $S$. aureus and its toxins in nasal polyposis, asthma, and atopic dermatitis pDC might serve as important promoters of Th2-based immune responses and staphylococcal colonization in these diseases (138-143).

Secondly, $S$. aureus induces a virulence factor-driven activation of pDC (Figure 1B, right panel). Our data suggest that pathogendriven activation of $\mathrm{pDC}$ enhances polyclonal $\mathrm{B}$ cell expansion and the development of suppressory B cells that secrete IL-10. Indeed, depletion of B cells from PBMC increases IFN $\gamma$ production in response to $S$. aureus (Bekeredjian-Ding, unpublished observation). Activation of $\mathrm{pDC}$ by $S$. aureus might additionally promote the formation of Tregs (144), which develop in an IFN-I-dependent and -independent manner (17, 39, 145). Nevertheless, pDC-derived IFN- $\alpha$ is likely to enhance proinflammatory effects exerted by aberrant IC formed by Ig binding to protein A and deposited in the tissues (146), superantigen-mediated T cell activation (147), or invasion of epithelial cells (129). It is further unknown whether and how pDC contribute to $S$. aureus protein A-mediated expansion of B cells and autoantibody production in Wegener's granulomatosis (148).

Taken together, the available studies illustrate that pDC (and IFN-I) fulfill partially unknown and conflicting roles in antibacterial defense and maintenance of tolerance. It is further unclear whether the active role of $\mathrm{pDC}$ in the memory response to S. aureus is to limit or to propagate the ongoing adaptive immune response. In views of the inflammatory potential of IFN-I future studies will need to evaluate whether therapeutical interference with pDC activation or IFN-I limits disease severity at a late stage of disease. However, suppression of IFN-I production in an early phase of infection might negatively affect immune recognition and favor intracellular persistence and development of chronic infections.

To date, it is further hard to foresee whether the induction of IFN-I by TLR7/9-based vaccine adjuvants will be beneficial by augmenting the preexisting memory response to $S$. aureus or converting its effector function to increased protection. It is also within the range of possibilities that these TLR agonists support the tolerogenic response exerted toward a commensal pathogen well-known to the host immune system.

\section{ACKNOWLEDGMENTS}

We would like to acknowledge all the cited and uncited researchers that dedicated their work to pDC and IFN-I function and we thank the Deutsche Forschungsgemeinschaft, Fritz-Bender-Stiftung, and Krebs- und Scharlach-Stiftung Mannheim for funding of our work on $\mathrm{pDC}$.

\section{REFERENCES}

1. Trinchieri G, Santoli D, Dee RR, Knowles BB. Anti-viral activity induced by culturing lymphocytes with tumor-derived or virus-transformed cells. Identification of the anti-viral activity as interferon and characterization of the human effector lymphocyte subpopulation. J Exp Med (1978) 147(5):1299-313. doi:10.1084/jem.147.5.1299

2. Asselin-Paturel C, Boonstra A, Dalod M, Durand I, Yessaad N, DezutterDambuyant C, et al. Mouse type I IFN-producing cells are immature APCs with plasmacytoid morphology. Nat Immunol (2001) 2(12):1144-50. doi:10. 1038/ni736

3. Colonna M, Trinchieri G, Liu YJ. Plasmacytoid dendritic cells in immunity. Nat Immunol (2004) 5(12):1219-26. doi:10.1038/ni1141

4. Liu YJ. IPC: professional type 1 interferon-producing cells and plasmacytoid dendritic cell precursors. Annu Rev Immunol (2005) 23:275-306. doi:10.1146/annurev.immunol.23.021704.115633

5. Swiecki M, Colonna M. Unraveling the functions of plasmacytoid dendritic cells during viral infections, autoimmunity, and tolerance. Immunol Rev (2010) 234(1):142-62. doi:10.1111/j.0105-2896.2009.00881.x

6. Michea P, Vargas P, Donnadieu MH, Rosemblatt M, Bono MR, Dumenil G, et al. Epithelial control of the human pDC response to extracellular bacteria. Eur J Immunol (2013) 43(5):1264-73. doi:10.1002/eji.201242990

7. Parcina M, Miranda-Garcia MA, Durlanik S, Ziegler S, Over B, Georg P, et al. Pathogen-triggered activation of plasmacytoid dendritic cells induces IL-10producing B cells in response to Staphylococcus aureus. J Immunol (2013) 190:1591-602. doi:10.4049/jimmunol.1201222

8. Parcina M, Wendt C, Goetz F, Zawatzky R, Zahringer U, Heeg K, et al. Staphylococcus aureus-induced plasmacytoid dendritic cell activation is based on an IgG-mediated memory response. J Immunol (2008) 181(6):3823-33. doi:10.4049/jimmunol.181.6.3823

9. Eloranta ML, Sandberg K, Ricciardi-Castagnoli P, Lindahl M, Alm GV. Production of interferon-alpha/beta by murine dendritic cell lines stimulated by virus and bacteria. Scand J Immunol (1997) 46(3):235-41. doi:10.1046/j.1365-3083. 1997.d01-120.x

10. Svensson H, Cederblad B, Lindahl M, Alm G. Stimulation of natural interferonalpha/beta-producing cells by Staphylococcus aureus. J Interferon Cytokine Res (1996) 16(1):7-16. doi:10.1089/jir.1996.16.7

11. Ronnblom L, Forsgren A, Alm GV. Characterization of interferons induced by bacteria and interferon-producing leukocytes in human peripheral blood. Infect Immun (1983) 40(1):126-32.

12. Smith EM, Johnson HM, Blalock JE. Staphylococcus aureus protein A induces the production of interferon-alpha in human lymphocytes and interferonalpha/beta in mouse spleen cells. J Immunol (1983) 130(2):773-6.

13. Wang Y, Swiecki M, McCartney SA, Colonna M. dsRNA sensors and plasmacytoid dendritic cells in host defense and autoimmunity. Immunol Rev (2011) 243(1):74-90. doi:10.1111/j.1600-065X.2011.01049.x

14. Kumagai Y, Kumar H, Koyama S, Kawai T, Takeuchi O, Akira S. Cutting edge: TLR-dependent viral recognition along with type I IFN positive feedback signaling masks the requirement of viral replication for IFN-\{alpha\} production in plasmacytoid dendritic cells. J Immunol (2009) 182(7):3960-4. doi:10.4049/jimmunol.0804315

15. Hornung V, Schlender J, Guenthner-Biller M, Rothenfusser S, Endres S, Conzelmann KK, et al. Replication-dependent potent IFN-alpha induction in human plasmacytoid dendritic cells by a single-stranded RNA virus. JImmunol (2004) 173(10):5935-43. doi:10.4049/jimmunol.173.10.5935

16. Schiller M, Parcina M, Heyder P, Foermer S, Ostrop J, Leo A, et al. Induction of type I IFN is a physiological immune reaction to apoptotic cell-derived membrane microparticles. J Immunol (2012) 189(4):1747-56. doi:10.4049/ jimmunol.1100631

17. Huber JP, Ramos HJ, Gill MA, Farrar JD. Cutting edge: type I IFN reverses human Th2 commitment and stability by suppressing GATA3. J Immunol (2010) 185(2):813-7. doi:10.4049/jimmunol.1000469

18. Jego G, Palucka AK, Blanck JP, Chalouni C, Pascual V, Banchereau J. Plasmacytoid dendritic cells induce plasma cell differentiation through type I interferon and interleukin 6. Immunity (2003) 19(2):225-34. doi:10.1016/S10747613(03)00208-5

19. Wang H, Peters N, Schwarze J. Plasmacytoid dendritic cells limit viral replication, pulmonary inflammation, and airway hyperresponsiveness in respiratory syncytial virus infection. J Immunol (2006) 177(9):6263-70. doi:10.4049/ jimmunol.177.9.6263 
20. Swiecki M, Gilfillan S, Vermi W, Wang Y, Colonna M. Plasmacytoid dendritic cell ablation impacts early interferon responses and antiviral $\mathrm{NK}$ and CD8(+) T cell accrual. Immunity (2010) 33(6):955-66. doi:10.1016/j.immuni. 2010.11.020

21. Swiecki M, Wang Y, Gilfillan S, Colonna M. Plasmacytoid dendritic cells contribute to systemic but not local antiviral responses to HSV infections. PLoS Pathog (2013) 9(10):e1003728. doi:10.1371/journal.ppat.1003728

22. Fitzgerald-Bocarsly P, Jacobs ES. Plasmacytoid dendritic cells in HIV infection: striking a delicate balance. J Leukoc Biol (2010) 87(4):609-20. doi:10.1189/jlb. 0909635

23. Miller E, Bhardwaj N. Dendritic cell dysregulation during HIV-1 infection. Immunol Rev (2013) 254(1):170-89. doi:10.1111/imr.12082

24. Wang FX, Huang J, Zhang H, Ma X. APOBEC3G upregulation by alpha interferon restricts human immunodeficiency virus type 1 infection in human peripheral plasmacytoid dendritic cells. J Gen Virol (2008) 89(Pt 3):722-30. doi:10.1099/vir.0.83530-0

25. Erikson E, Adam T, Schmidt S, Lehmann-Koch J, Over B, Goffinet C, et al. In vivo expression profile of the antiviral restriction factor and tumor-targeting antigen CD317/BST-2/HM1.24/tetherin in humans. Proc Natl Acad Sci U S A (2011) 108(33):13688-93. doi:10.1073/pnas.1101684108

26. Cao W, Bover L. Signaling and ligand interaction of ILT7: receptor-mediated regulatory mechanisms for plasmacytoid dendritic cells. Immunol Rev (2010) 234(1):163-76. doi:10.1111/j.0105-2896.2009.00867.x

27. Ronnblom L, Pascual V. The innate immune system in SLE: type I interferons and dendritic cells. Lupus (2008) 17(5):394-9. doi:10.1177/0961203308090020

28. Marshak-Rothstein A. Toll-like receptors in systemic autoimmune disease. Nat Rev Immunol (2006) 6(11):823-35. doi:10.1038/nri1957

29. Lamphier MS, Sirois CM, Verma A, Golenbock DT, Latz E. TLR9 and the recognition of self and non-self nucleic acids. Ann N Y Acad Sci (2006) 1082:31-43. doi:10.1196/annals.1348.005

30. Gilliet M, Cao W, Liu YJ. Plasmacytoid dendritic cells: sensing nucleic acids in viral infection and autoimmune diseases. Nat Rev Immunol (2008) 8(8):594-606. doi:10.1038/nri2358

31. Pay S, Pekel A, Simsek I, Musabak U, Erdem H, Dinc A, et al. Pronounced interferon-alpha production from plasmacytoid dendritic cells in patients with Behcet's disease following CpG D ODN stimulation. Clin Exp Rheumatol (2009) 27(2 Suppl 53):S37-42.

32. Blanco P, Palucka AK, Gill M, Pascual V, Banchereau J. Induction of dendritic cell differentiation by IFN-alpha in systemic lupus erythematosus. Science (2001) 294(5546):1540-3. doi:10.1126/science.1064890

33. Eloranta ML, Franck-Larsson K, Lovgren T, Kalamajski S, Ronnblom A, Rubin $\mathrm{K}$, et al. Type I interferon system activation and association with disease manifestations in systemic sclerosis. Ann Rheum Dis (2010) 69(7):1396-402. doi:10.1136/ard.2009.121400

34. Kiefer K, Oropallo MA, Cancro MP, Marshak-Rothstein A. Role of type I interferons in the activation of autoreactive B cells. Immunol Cell Biol (2012) 90(5):498-504. doi:10.1038/icb.2012.10

35. Novak N, Allam JP, Hagemann T, Jenneck C, Laffer S, Valenta R, et al. Characterization of FcepsilonRI-bearing CD123 blood dendritic cell antigen-2 plasmacytoid dendritic cells in atopic dermatitis. J Allergy Clin Immunol (2004) 114(2):364-70. doi:10.1016/j.jaci.2004.05.038

36. Gill MA, Bajwa G, George TA, Dong CC, Dougherty II, Jiang N, et al. Counterregulation between the FcepsilonRI pathway and antiviral responses in human plasmacytoid dendritic cells. J Immunol (2010) 184(11):5999-6006. doi:10.4049/jimmunol.0901194

37. Schroeder JT, Bieneman AP, Xiao H, Chichester KL, Vasagar K, Saini S, et al. TLR9- and FcepsilonRI-mediated responses oppose one another in plasmacytoid dendritic cells by down-regulating receptor expression. J Immunol (2005) 175(9):5724-31. doi:10.4049/jimmunol.175.9.5724

38. Tsukamoto N, Okada S, Onami Y, Sasaki Y, Umezawa K, Kawakami Y. Impairment of plasmacytoid dendritic cells for IFN production by the ligand for immunoglobulin-like transcript 7 expressed on human cancer cells. Clin Cancer Res (2009) 15(18):5733-43. doi:10.1158/1078-0432.CCR-09-0171

39. Matta BM, Castellaneta A, Thomson AW. Tolerogenic plasmacytoid DC. Eur J Immunol (2010) 40(10):2667-76. doi:10.1002/eji.201040839

40. Hadeiba H, Sato T, Habtezion A, Oderup C, Pan J, Butcher EC. CCR9 expression defines tolerogenic plasmacytoid dendritic cells able to suppress acute graft-versus-host disease. Nat Immunol (2008) 9(11):1253-60. doi:10.1038/ni. 1658

41. Ochando JC, Homma C, Yang Y, Hidalgo A, Garin A, Tacke F, et al. Alloantigenpresenting plasmacytoid dendritic cells mediate tolerance to vascularized grafts. Nat Immunol (2006) 7(6):652-62. doi:10.1038/ni1333

42. Abe M, Wang Z, de Creus A, Thomson AW. Plasmacytoid dendritic cell precursors induce allogeneic T-cell hyporesponsiveness and prolong heart graft survival. Am J Transplant (2005) 5(8):1808-19. doi:10.1111/j.1600-6143.2005. 00954.x

43. Demoulin S, Herfs M, Delvenne P, Hubert P. Tumor microenvironment converts plasmacytoid dendritic cells into immunosuppressive/tolerogenic cells: insight into the molecular mechanisms. J Leukoc Biol (2013) 93(3):343-52. doi:10.1189/jlb.0812397

44. Hong J, Gong ZJ. Human plasmacytoid dendritic cells from patients with chronic hepatitis B virus infection induce the generation of a higher proportion of CD4(+) and CD25(+) regulatory T cells compared with healthy patients. Hepatol Res (2008) 38(4):362-73. doi:10.1111/j.1872-034X.2007.00279.x

45. Lai WK, Curbishley SM, Goddard S, Alabraba E, Shaw J, Youster J, et al. Hepatitis $\mathrm{C}$ is associated with perturbation of intrahepatic myeloid and plasmacytoid dendritic cell function. J Hepatol (2007) 47(3):338-47. doi:10.1016/j.jhep.2007. 03.024

46. Malleret B, Maneglier B, Karlsson I, Lebon P, Nascimbeni M, Perie L, et al. Primary infection with simian immunodeficiency virus: plasmacytoid dendritic cell homing to lymph nodes, type I interferon, and immune suppression. Blood (2008) 112(12):4598-608. doi:10.1182/blood-2008-06-162651

47. Saxena V, Ondr JK, Magnusen AF, Munn DH, Katz JD. The countervailing actions of myeloid and plasmacytoid dendritic cells control autoimmune diabetes in the nonobese diabetic mouse. J Immunol (2007) 179(8):5041-53. doi:10.4049/jimmunol.179.8.5041

48. Bailey-Bucktrout SL, Caulkins SC, Goings G, Fischer JA, Dzionek A, Miller SD. Cutting edge: central nervous system plasmacytoid dendritic cells regulate the severity of relapsing experimental autoimmune encephalomyelitis. J Immunol (2008) 180(10):6457-61. doi:10.4049/jimmunol.180.10.6457

49. Jongbloed SL, Benson RA, Nickdel MB, Garside P, McInnes IB, Brewer JM. Plasmacytoid dendritic cells regulate breach of self-tolerance in autoimmune arthritis. J Immunol (2009) 182(2):963-8. doi:10.4049/jimmunol.182.2.963

50. Goubier A, Dubois B, Gheit H, Joubert G, Villard-Truc F, Asselin-Paturel C, et al. Plasmacytoid dendritic cells mediate oral tolerance. Immunity (2008) 29(3):464-75. doi:10.1016/j.immuni.2008.06.017

51. Parcina M, Schiller M, Gierschke A, Heeg K, Bekeredjian-Ding I. PDC expressing CD36, CD61 and IL-10 may contribute to propagation of immune tolerance. Autoimmunity (2009) 42(4):353-5. doi:10.1080/08916930902831969

52. Bonnefoy F, Perruche S, Couturier M, Sedrati A, Sun Y, Tiberghien P, et al. Plasmacytoid dendritic cells play a major role in apoptotic leukocyteinduced immune modulation. J Immunol (2011) 186(10):5696-705. doi:10. 4049/jimmunol.1001523

53. Martin-Gayo E, Sierra-Filardi E, Corbi AL, Toribio ML. Plasmacytoid dendritic cells resident in human thymus drive natural Treg cell development. Blood (2010) 115(26):5366-75. doi:10.1182/blood-2009-10-248260

54. Ito T, Yang M, Wang YH, Lande R, Gregorio J, Perng OA, et al. Plasmacytoid dendritic cells prime IL-10-producing T regulatory cells by inducible costimulator ligand. J Exp Med (2007) 204(1):105-15. doi:10.1084/jem.20061660

55. Manches O, Munn D, Fallahi A, Lifson J, Chaperot L, Plumas J, et al. HIVactivated human plasmacytoid DCs induce Tregs through an indoleamine 2,3-dioxygenase-dependent mechanism. J Clin Invest (2008) 118(10):3431-9. doi:10.1172/JCI34823

56. Moseman EA, Liang X, Dawson AJ, Panoskaltsis-Mortari A, Krieg AM, Liu YJ, et al. Human plasmacytoid dendritic cells activated by CpG oligodeoxynucleotides induce the generation of CD4+CD25+ regulatory T cells. J Immunol (2004) 173(7):4433-42. doi:10.4049/jimmunol.173.7.4433

57. Ouabed A, Hubert FX, Chabannes D, Gautreau L, Heslan M, Josien R. Differential control of $\mathrm{T}$ regulatory cell proliferation and suppressive activity by mature plasmacytoid versus conventional spleen dendritic cells. J Immunol (2008) 180(9):5862-70. doi:10.4049/jimmunol.180.9.5862

58. Gilliet M, Liu YJ. Human plasmacytoid-derived dendritic cells and the induction of T-regulatory cells. Hum Immunol (2002) 63(12):1149-55. doi:10.1016/ S0198-8859(02)00753-X 
59. Gilliet M, Liu YJ. Generation of human CD8 T regulatory cells by CD40 ligandactivated plasmacytoid dendritic cells. J Exp Med (2002) 195(6):695-704. doi:10.1084/jem.20011603

60. Tokita D, Sumpter TL, Raimondi G, Zahorchak AF, Wang Z, Nakao A, et al. Poor allostimulatory function of liver plasmacytoid DC is associated with pro-apoptotic activity, dependent on regulatory T cells. J Hepatol (2008) 49(6):1008-18. doi:10.1016/j.jhep.2008.07.028

61. Ogata M, Ito T, Shimamoto K, Nakanishi T, Satsutani N, Miyamoto R, et al. Plasmacytoid dendritic cells have a cytokine-producing capacity to enhance ICOS ligand-mediated IL-10 production during T-cell priming. Int Immunol (2013) 25(3):171-82. doi:10.1093/intimm/dxs103

62. Manches O, Fernandez MV, Plumas J, Chaperot L, Bhardwaj N. Activation of the noncanonical NF-kappaB pathway by HIV controls a dendritic cell immunoregulatory phenotype. Proc Natl Acad Sci U S A (2012) 109(35):14122-7. doi:10.1073/pnas.1204032109

63. Boasso A, Royle CM, Doumazos S, Aquino VN, Biasin M, Piacentini L, et al. Overactivation of plasmacytoid dendritic cells inhibits antiviral T-cell responses: a model for HIV immunopathogenesis. Blood (2011) 118(19):5152-62. doi:10.1182/blood-2011-03-344218

64. Tokita D, Mazariegos GV, Zahorchak AF, Chien N, Abe M, Raimondi G, et al. High PD-L1/CD86 ratio on plasmacytoid dendritic cells correlates with elevated T-regulatory cells in liver transplant tolerance. Transplantation (2008) 85(3):369-77. doi:10.1097/TP.0b013e3181612ded

65. Chen W, Liang X, Peterson AJ, Munn DH, Blazar BR. The indoleamine 2,3-dioxygenase pathway is essential for human plasmacytoid dendritic cell-induced adaptive $\mathrm{T}$ regulatory cell generation. J Immunol (2008) 181(8):5396-404. doi:10.4049/jimmunol.181.8.5396

66. Munn DH, Sharma MD, Hou D, Baban B, Lee JR, Antonia SJ, et al. Expression of indoleamine 2,3-dioxygenase by plasmacytoid dendritic cells in tumordraining lymph nodes. J Clin Invest (2004) 114(2):280-90. doi:10.1172/ JCI21583E1

67. Sharma MD, Baban B, Chandler P, Hou DY, Singh N, Yagita H, et al. Plasmacytoid dendritic cells from mouse tumor-draining lymph nodes directly activate mature Tregs via indoleamine 2,3-dioxygenase. J Clin Invest (2007) 117(9):2570-82. doi:10.1172/JCI31911

68. Contractor N, Louten J, Kim L, Biron CA, Kelsall BL. Cutting edge: Peyer's patch plasmacytoid dendritic cells (pDCs) produce low levels of type I interferons: possible role for IL-10, TGFbeta, and prostaglandin E2 in conditioning a unique mucosal pDC phenotype. J Immunol (2007) 179(5):2690-4. doi:10.4049/jimmunol.179.5.2690

69. Castellaneta A, Sumpter TL, Chen L, Tokita D, Thomson AW. NOD2 ligation subverts IFN-alpha production by liver plasmacytoid dendritic cells and inhibits their $\mathrm{T}$ cell allostimulatory activity via B7-H1 up-regulation. JImmunol (2009) 183(11):6922-32. doi:10.4049/jimmunol.0900582

70. Li L, Liu S, Zhang T, Pan W, Yang X, Cao X. Splenic stromal microenvironment negatively regulates virus-activated plasmacytoid dendritic cells through TGFbeta. J Immunol (2008) 180(5):2951-6. doi:10.4049/jimmunol.180.5.2951

71. Bonnefoy F, Couturier M, Clauzon A, Remy-Martin JP, Gaugler B, Tiberghien $\mathrm{P}$, et al. TGF-beta-exposed plasmacytoid dendritic cells participate in Th17 commitment. J Immunol (2011) 186(11):6157-64. doi:10.4049/jimmunol. 1002497

72. Bekeredjian-Ding I, Schafer M, Hartmann E, Pries R, Parcina M, Schneider $\mathrm{P}$, et al. Tumour-derived prostaglandin $\mathrm{E}$ and transforming growth factorbeta synergize to inhibit plasmacytoid dendritic cell-derived interferon-alpha. Immunology (2009) 128(3):439-50. doi:10.1111/j.1365-2567.2009.03134.x

73. Fabricius D, Neubauer M, Mandel B, Schutz C, Viardot A, Vollmer A, et al. Prostaglandin E2 inhibits IFN-alpha secretion and Th1 costimulation by human plasmacytoid dendritic cells via E-prostanoid 2 and Eprostanoid 4 receptor engagement. J Immunol (2010) 184(2):677-84. doi:10. 4049/jimmunol.0902028

74. Eloranta ML, Lovgren T, Finke D, Mathsson L, Ronnelid J, Kastner B, et al. Regulation of the interferon-alpha production induced by RNA-containing immune complexes in plasmacytoid dendritic cells. Arthritis Rheum (2009) 60(8):2418-27. doi:10.1002/art.24686

75. Poth JM, Coch C, Busch N, Boehm O, Schlee M, Janke M, et al. Monocytemediated inhibition of TLR9-dependent IFN-alpha induction in plasmacytoid dendritic cells questions bacterial DNA as the active ingredient of bacterial lysates. J Immunol (2010) 185(12):7367-73. doi:10.4049/jimmunol. 1001798

76. Huber JP, Farrar JD. Regulation of effector and memory T-cell functions by type I interferon. Immunology (2011) 132(4):466-74. doi:10.1111/j.1365-2567. 2011.03412.x

77. Marshall HD, Urban SL, Welsh RM. Virus-induced transient immune suppression and the inhibition of T cell proliferation by type I interferon. J Virol (2011) 85(12):5929-39. doi:10.1128/JVI.02516-10

78. Danis VA, Kulesz AJ, Nelson DS, Brooks PM. Cytokine regulation of human monocyte interleukin-1 (IL-1) production in vitro. Enhancement of IL-1 production by interferon (IFN) gamma, tumour necrosis factor-alpha, IL-2 and IL-1, and inhibition by IFN-alpha. Clin Exp Immunol (1990) 80(3):435-43. doi:10.1111/j.1365-2249.1990.tb03306.x

79. Newton RC. Effect of interferon on the induction of human monocyte secretion of interleukin-1 activity. Immunology (1985) 56(3):441-9.

80. Levings MK, Sangregorio R, Galbiati F, Squadrone S, de Waal Malefyt R, Roncarolo MG. IFN-alpha and IL-10 induce the differentiation of human type $1 \mathrm{~T}$ regulatory cells. J Immunol (2001) 166(9):5530-9. doi:10.4049/jimmunol.166. 9.5530

81. Reznikov LL, Puren AJ, Fantuzzi G, Muhl H, Shapiro L, Yoon DY, et al. Spontaneous and inducible cytokine responses in healthy humans receiving a single dose of IFN-alpha2b: increased production of interleukin-1 receptor antagonist and suppression of IL-1-induced IL-8. J Interferon Cytokine Res (1998) 18(10):897-903. doi:10.1089/jir.1998.18.897

82. Tilg H, Vogel W, Dinarello CA. Interferon-alpha induces circulating tumor necrosis factor receptor p55 in humans. Blood (1995) 85(2):433-5.

83. Erickson S, Sangfelt O, Castro J, Heyman M, Einhorn S, Grander D. Interferonalpha inhibits proliferation in human $\mathrm{T}$ lymphocytes by abrogation of interleukin 2-induced changes in cell cycle-regulatory proteins. Cell Growth Differ (1999) 10(8):575-82.

84. Gracias DT, Stelekati E, Hope JL, Boesteanu AC, Doering TA, Norton J, et al. The microRNA miR-155 controls CD8(+) T cell responses by regulating interferon signaling. Nat Immunol (2013) 14(6):593-602. doi:10.1038/ni.2576

85. Schreiner B, Mitsdoerffer M, Kieseier BC, Chen L, Hartung HP, Weller M, et al. Interferon-beta enhances monocyte and dendritic cell expression of B7H1 (PD-L1), a strong inhibitor of autologous T-cell activation: relevance for the immune modulatory effect in multiple sclerosis. J Neuroimmunol (2004) 155(1-2):172-82. doi:10.1016/j.jneuroim.2004.06.013

86. Soos JM, Johnson HM. Type I interferon inhibition of superantigen stimulation: implications for treatment of superantigen-associated disease. J Interferon Cytokine Res (1995) 15(1):39-45. doi:10.1089/jir.1995.15.39

87. Yen A, Lewin D, Fairchild D. Interferon inhibits PWM induced B cell differentiation but not onset of proliferation. Leuk Res (1982) 6(2):221-9. doi:10.1016/0145-2126(82)90028-5

88. Gongora R, Stephan RP, Zhang Z, Cooper MD. An essential role for Daxx in the inhibition of B lymphopoiesis by type I interferons. Immunity (2001) 14(6):727-37. doi:10.1016/S1074-7613(01)00152-2

89. Dikopoulos N, Bertoletti A, Kroger A, Hauser H, Schirmbeck R, Reimann J. Type I IFN negatively regulates CD8+ T cell responses through IL-10producing CD4+ T regulatory 1 cells. J Immunol (2005) 174(1):99-109. doi:10.4049/jimmunol.174.1.99

90. Bogdan C, Mattner J, Schleicher U. The role of type I interferons in nonviral infections. Immunol Rev (2004) 202:33-48. doi:10.1111/j.0105-2896. 2004.00207.x

91. Birke C, Peter HH, Langenberg U, Muller-Hermes WJ, Peters JH, Heitmann J, et al. Mycoplasma contamination in human tumor cell lines: effect on interferon induction and susceptibility to natural killing. J Immunol (1981) 127(1):94-8.

92. Duc-Goiran P, Zernicki L. Interferons induced by Chlamydia trachomatis in human lymphocyte cultures. Biomedicine (1981) 34(2):88-93.

93. Giacomini E, Iona E, Ferroni L, Miettinen M, Fattorini L, Orefici G, et al. Infection of human macrophages and dendritic cells with Mycobacterium tuberculosis induces a differential cytokine gene expression that modulates $\mathrm{T}$ cell response. J Immunol (2001) 166(12):7033-41. doi:10.4049/jimmunol.166.12. 7033

94. Hess CB, Niesel DW, Cho YJ, Klimpel GR. Bacterial invasion of fibroblasts induces interferon production. J Immunol (1987) 138(11):3949-53. 
95. Nakane A, Minagawa T. Alternative induction of IFN-alpha and IFN-gamma by Listeria monocytogenes in human peripheral blood mononuclear leukocyte cultures. J Immunol (1981) 126(6):2139-42.

96. Remoli ME, Giacomini E, Lutfalla G, Dondi E, Orefici G, Battistini A, et al. Selective expression of type I IFN genes in human dendritic cells infected with Mycobacterium tuberculosis. J Immunol (2002) 169(1):366-74. doi:10.4049/jimmunol.169.1.366

97. Kasahara T, Harada H, Shioiri-Nakano K, Wakasugi H, Imai M, Mayumi M, et al. Potentiation of natural killer cell activity of human lymphocytes in vitro: the participation of interferon in stimulation with Staphylococcus aureus Cowan I bacteria but not with protein A. Immunology (1982) 45(4):687-95.

98. Gore MM, Kedarnath N, Banerjea AC, Ranbhor SV, Ghosh SN. Acid labile type alpha interferon induction by formalinized Staphylococcus aureus (Cowan I) in human mononuclear leukocytes. Indian J Med Res (1983) 77:770-6.

99. Sander LE, Davis MJ, Boekschoten MV, Amsen D, Dascher CC, Ryffel B, et al. Detection of prokaryotic mRNA signifies microbial viability and promotes immunity. Nature (2011) 474(7351):385-9. doi:10.1038/nature10072

100. van der Molen RG, Sprengers D, Binda RS, de Jong EC, Niesters HG, Kusters JG, et al. Functional impairment of myeloid and plasmacytoid dendritic cells of patients with chronic hepatitis B. Hepatology (2004) 40(3):738-46. doi:10.1002/hep.20366

101. Veckman V, Julkunen I. Streptococcus pyogenes activates human plasmacytoid and myeloid dendritic cells. J Leukoc Biol (2008) 83(2):296-304. doi:10.1189/ jlb.0707457

102. Balmelli C, Vincent IE, Rau H, Guzylack-Piriou L, McCullough K, Summerfield A. Fc gamma RII-dependent sensitisation of natural interferon-producing cells for viral infection and interferon-alpha responses. Eur J Immunol (2005) 35(8):2406-15. doi:10.1002/eji.200525998

103. Chehadeh W, Bouzidi A, Alm G, Wattre P, Hober D. Human antibodies isolated from plasma by affinity chromatography increase the coxsackievirus B4induced synthesis of interferon-alpha by human peripheral blood mononuclear cells in vitro. J Gen Virol (2001) 82(Pt 8):1899-907.

104. Green JA, Martin EM, Mullen BT, Lum T, Pitrak D, Green DS, et al. Immunespecific immunoglobulin G-mediated enhancement of human immunodeficiency virus-induced IFN-alpha production. J Interferon Cytokine Res (2002) 22(12):1201-8. doi:10.1089/10799900260475722

105. Guzylack-Piriou L, Bergamin F, Gerber M, McCullough KC, Summerfield A. Plasmacytoid dendritic cell activation by foot-and-mouth disease virus requires immune complexes. Eur J Immunol (2006) 36(7):1674-83. doi:10. 1002/eji.200635866

106. Hober D, Chehadeh W, Bouzidi A, Wattre P. Antibody-dependent enhancement of coxsackievirus B4 infectivity of human peripheral blood mononuclear cells results in increased interferon-alpha synthesis. J Infect Dis (2001) 184(9):1098-108. doi:10.1086/323801

107. Palmer P, Charley B, Rombaut B, Daeron M, Lebon P. Antibody-dependent induction of type I interferons by poliovirus in human mononuclear blood cells requires the type II fcgamma receptor (CD32). Virology (2000) 278(1):86-94. doi:10.1006/viro.2000.0627

108. Silverman GJ, Goodyear CS. Confounding B-cell defences: lessons from a staphylococcal superantigen. Nat Rev Immunol (2006) 6(6):465-75. doi:10. 1038/nri1853

109. Kaplan A, Ma J, Kyme P, Wolf AJ, Becker CA, Tseng CW, et al. Failure to induce IFN-beta production during Staphylococcus aureus infection contributes to pathogenicity. J Immunol (2012) 189(9):4537-45. doi:10.4049/ jimmunol.1201111

110. Munoz-Planillo R, Franchi L, Miller LS, Nunez G. A critical role for hemolysins and bacterial lipoproteins in Staphylococcus aureus-induced activation of the Nlrp3 inflammasome. J Immunol (2009) 183(6):3942-8. doi:10.4049/ jimmunol.0900729

111. Franchi L, Kanneganti TD, Dubyak GR, Nunez G. Differential requirement of $\mathrm{P} 2 \mathrm{X} 7$ receptor and intracellular $\mathrm{K}+$ for caspase- 1 activation induced by intracellular and extracellular bacteria. J Biol Chem (2007) 282(26):18810-8. doi:10.1074/jbc.M610762200

112. Shimada T, Park BG, Wolf AJ, Brikos C, Goodridge HS, Becker CA, et al. Staphylococcus aureus evades lysozyme-based peptidoglycan digestion that links phagocytosis, inflammasome activation, and IL-1beta secretion. Cell Host Microbe (2010) 7(1):38-49. doi:10.1016/j.chom.2009.12.008
113. Craven RR, Gao X, Allen IC, Gris D, Bubeck Wardenburg J, McElvaniaTekippe E, et al. Staphylococcus aureus alpha-hemolysin activates the NLRP3inflammasome in human and mouse monocytic cells. PLoS One (2009) 4(10):e7446. doi:10.1371/journal.pone.0007446

114. Mariathasan S, Weiss DS, Newton K, McBride J, O’Rourke K, Roose-Girma M, et al. Cryopyrin activates the inflammasome in response to toxins and ATP. Nature (2006) 440(7081):228-32. doi:10.1038/nature04515

115. Bekeredjian-Ding IB, Wagner M, Hornung V, Giese T, Schnurr M, Endres S, et al. Plasmacytoid dendritic cells control TLR7 sensitivity of naive B cells via type I IFN. J Immunol (2005) 174(7):4043-50. doi:10.4049/jimmunol.174.7. 4043

116. Ding C, Cai Y, Marroquin J, Ildstad ST, Yan J. Plasmacytoid dendritic cells regulate autoreactive $\mathrm{B}$ cell activation via soluble factors and in a cell-to-cell contact manner. J Immunol (2009) 183(11):7140-9. doi:10.4049/jimmunol. 0901175

117. Shaw J, Wang YH, Ito T, Arima K, Liu YJ. Plasmacytoid dendritic cells regulate B-cell growth and differentiation via CD70. Blood (2010) 115(15):3051-7. doi:10.1182/blood-2009-08-239145

118. Berggren O, Hagberg N, Weber G, Alm GV, Ronnblom L, Eloranta ML. B lymphocytes enhance interferon-alpha production by plasmacytoid dendritic cells. Arthritis Rheum (2012) 64(10):3409-19. doi:10.1002/art.34599

119. Georg P, Bekeredjian-Ding I. Plasmacytoid dendritic cells control B cell-derived IL-10 production. Autoimmunity (2012) 45(8):579-83. doi:10.3109/08916934. 2012.719955

120. Aoki N, Ohno Y. Enhancement of the B-cell response to Staphylococcus aureus Cowan strain 1 by natural human gamma interferon. Immunology (1987) 60(1):51-5

121. Oka H, Hirohata S. Regulation of human B cell responsiveness by interferonalpha: interferon-alpha-mediated suppression of B cell function is reversed through direct interactions between monocytes and B cells. Cell Immunol (1993) 146(2):238-48. doi:10.1006/cimm.1993.1023

122. Oka H, Hirohata S, Inoue T, Ito K. Effects of interferon-alpha on human B cell responsiveness: biphasic effects in cultures stimulated with Staphylococcus aureus. Cell Immunol (1992) 139(2):478-92. doi:10.1016/0008-8749(92) 90087-6

123. Fillatreau S. Cytokine-producing B cells as regulators of pathogenic and protective immune responses. Ann Rheum Dis (2013) 72(Suppl 2):ii80-4. doi:10.1136/annrheumdis-2012-202253

124. Mancuso G, Midiri A, Biondo C, Beninati C, Zummo S, Galbo R, et al. Type I IFN signaling is crucial for host resistance against different species of pathogenic bacteria. J Immunol (2007) 178(5):3126-33. doi:10.4049/jimmunol.178. 5.3126

125. Kelly-Scumpia KM, Scumpia PO, Delano MJ, Weinstein JS, Cuenca AG, Wynn $\mathrm{JL}$, et al. Type I interferon signaling in hematopoietic cells is required for survival in mouse polymicrobial sepsis by regulating CXCL10. J Exp Med (2010) 207(2):319-26. doi:10.1084/jem.20091959

126. Weighardt H, Kaiser-Moore S, Schlautkotter S, Rossmann-Bloeck T, Schleicher U, Bogdan C, et al. Type I IFN modulates host defense and late hyperinflammation in septic peritonitis. J Immunol (2006) 177(8):5623-30. doi:10.4049/jimmunol.177.8.5623

127. Rosztoczy I. Priming of Staphylococcus aureus-induced interferon production in human buffy coat leukocytes by human interferon-alpha pretreatment. Acta Microbiol Hung (1988) 35(3):323-5.

128. Oldenburg M, Kruger A, Ferstl R, Kaufmann A, Nees G, Sigmund A, et al. TLR13 recognizes bacterial 23S rRNA devoid of erythromycin resistance-forming modification. Science (2012) 337(6098):1111-5. doi:10.1126/science.1220363

129. Martin FJ, Gomez MI, Wetzel DM, Memmi G, O’Seaghdha M, Soong G, et al. Staphylococcus aureus activates type I IFN signaling in mice and humans through the $\mathrm{Xr}$ repeated sequences of protein A. J Clin Invest (2009) 119(7):1931-9. doi:10.1172/JCI35879

130. Parker D, Prince A. Staphylococcus aureus induces type I IFN signaling in dendritic cells via TLR9. J Immunol (2012) 189(8):4040-6. doi:10.4049/jimmunol. 1201055

131. Navarini AA, Recher M, Lang KS, Georgiev P, Meury S, Bergthaler A, et al. Increased susceptibility to bacterial superinfection as a consequence of innate antiviral responses. Proc Natl Acad Sci U S A (2006) 103(42):15535-9. doi:10.1073/pnas.0607325103 
132. Cousens LP, Orange JS, Su HC, Biron CA. Interferon-alpha/beta inhibition of interleukin 12 and interferon-gamma production in vitro and endogenously during viral infection. Proc Natl Acad Sci U S A (1997) 94(2):634-9. doi:10.1073/pnas.94.2.634

133. Roquilly A, Gautreau L, Segain JP, de Coppet P, Sebille V, Jacqueline $\mathrm{C}$, et al. CpG-ODN and MPLA prevent mortality in a murine model of post-hemorrhage-Staphyloccocus aureus pneumonia. PLoS One (2010) 5(10):e13228. doi:10.1371/journal.pone.0013228

134. Lizak M, Yarovinsky TO. Phospholipid scramblase 1 mediates type i interferoninduced protection against staphylococcal alpha-toxin. Cell Host Microbe (2012) 11(1):70-80. doi:10.1016/j.chom.2011.12.004

135. Hammarstrom L, Granstrom M, Oxelius V, Persson MA, Smith CI. IgG subclass distribution of antibodies against $S$. aureus teichoic acid and alphatoxin in normal and immunodeficient donors. Clin Exp Immunol (1984) 55(3):593-601.

136. Hammarstrom L, Persson MA, Smith CI. Subclass distribution of human antiStaphylococcus aureus alpha toxin antibodies: suggestion of an $\operatorname{IgG1} \operatorname{IgA1}$, IgG4 switch pattern. Scand J Immunol (1984) 20(3):247-50. doi:10.1111/j. 1365-3083.1984.tb00998.x

137. Monteil MA, Kaniuk AS, Hobbs JR. Staphylococcal opsonization and antiStaphylococcus aureus IgG subclass antibodies in patients with severe or recurrent S. aureus infections. FEMS Microbiol Immunol (1990) 2(5-6):259-62. doi:10.1016/0928-8244(90)90020-S

138. Bachert C, van Steen K, Zhang N, Holtappels G, Cattaert T, Maus B, et al. Specific IgE against Staphylococcus aureus enterotoxins: an independent risk factor for asthma. J Allergy Clin Immunol (2012) 130(2):376.e-81.e. doi:10.1016/j. jaci.2012.05.012

139. Foreman A, Holtappels G, Psaltis AJ, Jervis-Bardy J, Field J, Wormald PJ, et al. Adaptive immune responses in Staphylococcus aureus biofilm-associated chronic rhinosinusitis. Allergy (2011) 66(11):1449-56. doi:10.1111/j.13989995.2011.02678.x

140. Krysko O, Holtappels G, Zhang N, Kubica M, Deswarte K, Derycke L, et al. Alternatively activated macrophages and impaired phagocytosis of $S$. aureus in chronic rhinosinusitis. Allergy (2011) 66(3):396-403. doi:10.1111/j.13989995.2010.02498.x

141. Baker BS. The role of microorganisms in atopic dermatitis. Clin Exp Immunol (2006) 144(1):1-9. doi:10.1111/j.1365-2249.2005.02980.x

142. Takai T, Ikeda S. Barrier dysfunction caused by environmental proteases in the pathogenesis of allergic diseases. Allergol Int (2011) 60(1):25-35. doi:10.2332/allergolint.10-RAI-0273
143. Hohchi N, Hashida K, Ohkubo J, Wakasugi T, Mori T, Nguyen KH, et al. Synergism of Staphylococcus aureus colonization and allergic reaction in the nasal cavity in mice. Int Arch Allergy Immunol (2012) 159(1):33-40. doi:10.1159/000335200

144. Taylor AL, Llewelyn MJ. Superantigen-induced proliferation of human CD4+CD25- $\mathrm{T}$ cells is followed by a switch to a functional regulatory phenotype. J Immunol (2010) 185(11):6591-8. doi:10.4049/jimmunol. 1002416

145. Trinchieri G. Type I interferon: friend or foe? J Exp Med (2010) 207(10):2053-63. doi:10.1084/jem.20101664

146. Anderson AL, Sporici R, Lambris J, Larosa D, Levinson AI. Pathogenesis of B-cell superantigen-induced immune complex-mediated inflammation. Infect Immun (2006) 74(2):1196-203. doi:10.1128/IAI.74.2.1196-1203.2006

147. Chowdhary VR, Tilahun AY, Clark CR, Grande JP, Rajagopalan G. Chronic exposure to staphylococcal superantigen elicits a systemic inflammatory disease mimicking lupus. J Immunol (2012) 189(4):2054-62. doi:10.4049/jimmunol. 1201097

148. Voswinkel J, Muller A, Lamprecht P. Is PR3-ANCA formation initiated in Wegener's granulomatosis lesions? Granulomas as potential lymphoid tissue maintaining autoantibody production. Ann N Y Acad Sci (2005) 1051:12-9. doi:10.1196/annals.1361.042

Conflict of Interest Statement: The authors declare that the research was conducted in the absence of any commercial or financial relationships that could be construed as a potential conflict of interest.

Received: 02 February 2014; accepted: 08 May 2014; published online: 23 May 2014. Citation: Bekeredjian-Ding I, Greil J, Ammann S and Parcina M (2014) Plasmacytoid dendritic cells: neglected regulators of the immune response to Staphylococcus aureus. Front. Immunol. 5:238. doi: 10.3389/fimmu.2014.00238

This article was submitted to Microbial Immunology, a section of the journal Frontiers in Immunology.

Copyright (c) 2014 Bekeredjian-Ding, Greil, Ammann and Parcina. This is an openaccess article distributed under the terms of the Creative Commons Attribution License (CC BY). The use, distribution or reproduction in other forums is permitted, provided the original author(s) or licensor are credited and that the original publication in this journal is cited, in accordance with accepted academic practice. No use, distribution or reproduction is permitted which does not comply with these terms. 